\title{
TAXONOMY OF THE CONODONT SPECIES OZARKODINA POLINCLINATA (NICOLL ET REXROAD) IN THE SILURIAN OF ESTONIA
}

\begin{abstract}
The study of the evolution of the conodont apparatus Ozarkodina polinclinata (one of the most frequent species in the celloni and amorphognathoides zones interval in Estonia) resulted in the recognition of two types of $\mathrm{Pa}$ elements in it. These elements differ in the number and construction of the denticles on them, and are described here as the $\mathrm{Pa}$ elements of two different subspecies named as $O$. polinclinata polinclinata (Nicoll et Rexroad) and $O$. polinclinata estonica ssp. $\mathrm{n}$. The distribution intervals of these two subspecies in Estonia are separated by an interregnum up to about $10 \mathrm{~m}$ thick in some sections. This interregnum coincides with the boundary between the celloni and amorphognathoides zones.
\end{abstract}

As a rule, conodonts are rare in the major part of the Llandovery as well as the lower Wenlock in Estonia. Only argillaceous sediments of the extensive late Llandovery transgression here have yielded a rich fauna of the celloni and amorphognathoides zones. Some of the well-preserved conodonts from this stratigraphic interval have been already studied (Männik and Aldridge, 1989).

The purpose of the present paper is to describe the variability and evolution of the conodont apparatus Ozarkodina polinclinata - one of the most frequent multielement species of the celloni and amorphognathoides zones in Estonia. The material studied comes mostly from the Jōhve and Viki boring cores, but also from the Nässumaa, Leisi, Lihula, and Viluvere cores (see Fig. 1).

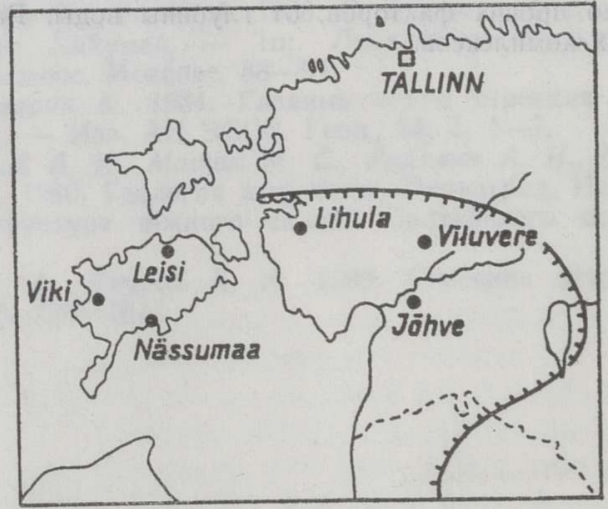

Fig. 1. Distribution of the studied sections. The indented line indicates the contour of the distribution area of the upper Llandovery-lower Wenlock rocks.

* Eesti Teaduste Akadeemia Geoloogia Instituut (Institute of Geology, Estonian Academy of Sciences). EE0105 Tallinn, Estonia pst. 7. Estonia. 
Nicoll and Rexroad (1968) noted great variability of the formal species Spathognathodus polinclinatus s. f., later taken as the $\mathrm{Pa}$ element of the apparatus O. polinclinata (Cooper, 1977; Uyeno and Barnes, 1981; etc.). The study of the Estonian collection resulted in the recognition of two types of the $\mathrm{Pa}$ element with succeeding local ranges (see Figs. 2-5). Moreover, these ranges are separated by an interregnum (up to about $10 \mathrm{~m}$ thick in some sections) lacking 0 . polinclinata. This interregnum coincides with the boundary interval between the celloni and amorphognathoides zones (Fig. 2).

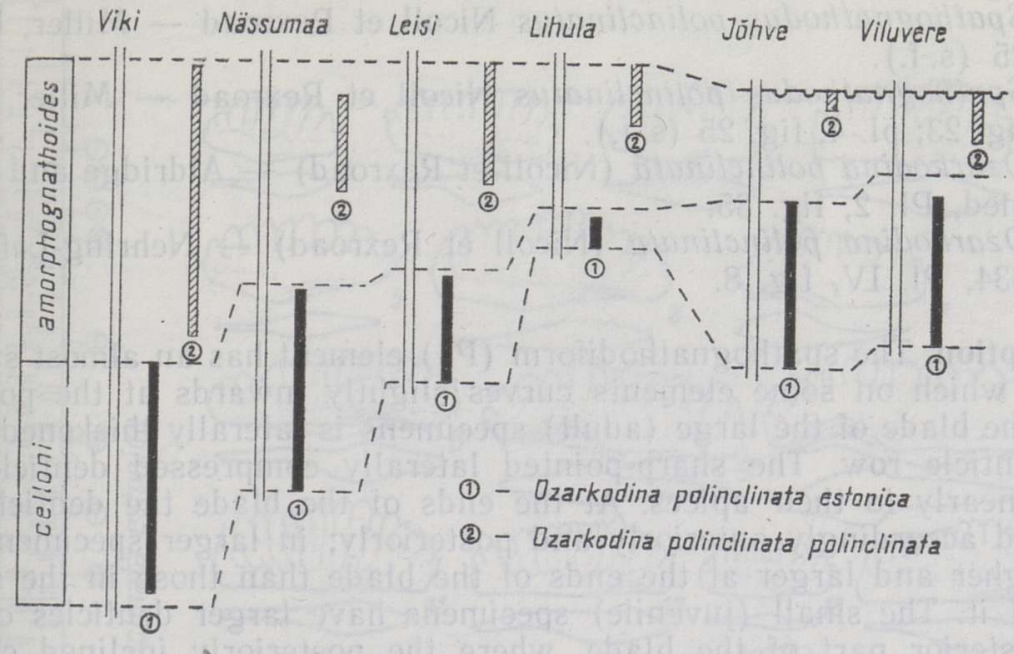

Fig. 2. Distribution of $O$. polinclinata estonica and $O$. polinclinata polinclinata in the studied sections.

In the present paper the apparatuses of $O$. polinclinata with different $\mathrm{Pa}$ elements are described as its subspecies (see the systematic part) and are named as $O$. polinclinata polinclinata (Nicoll et Rexroad) and $O$. polinclinata estonica. It is noteworthy that although the $\mathrm{Pa}$ elements of these subspecies are quite different, the other elements are almost identical (Pl., figs. 3, 5-11, 13, 16, 18, 19). The new subspecies is stratigraphically older and its range is restricted to the celloni Zone; the nominal subspecies appears in the amorphognathoides Zone (Figs. 2-5).

The previous treatments confirm the conclusions made by studying the Estonian material. The $\mathrm{Pa}$ elements of $O$. polinclinata, similar to $O$. polinclinata estonica from Estonia, have been found together with Pterospathodus celloni from several parts of Europe and North America (Aldridge, 1972, 1985; Rexroad and Nicoll, 1972; Cooper, 1977; Liebe and Rexroad, 1977; Uyeno and Barnes, 1981, 1983). In the same regions O. polinclinata polinclinata occurs within the limits of the amorphognathoides Zone (Rexroad and Nicoll, 1972; Miller, 1976, 1978; Aldridge and Mohamed, 1982; Nehring-Lefeld, 1985).

Below only the descriptions of $\mathrm{Pa}$ elements (the diagnostic ones) of $O$. polinclinata polinclinata and $O$. polinclinata estonica are given. The other elements ( $\mathrm{Pb}, \mathrm{M}, \mathrm{Sc}, \mathrm{Sb}$, and $\mathrm{Sa}$ ) of these subspecies are similar and have been completely described earlier (see Nicoll and Rexroad, 1968; Cooper, 1977; etc.). In synonymy only the earlier data on the $\mathrm{Pa}$ element are given.

Specimens described here are deposited in the Institute of Geology of the Estonian Academy of Sciences. 


\section{Systematic Part}

Ozarkodina polinclinata polinclinata (Nicoll et Rexroad) Plate, figs. $8,10-20$

1968 Spathognathodus polinclinatus sp. n. - Nicoll and Rexroad, p. 60, Pl. 2, figs. 19,20 (s. f.).

1972 Spathognathodus polinclinatus Nicoll et Rexroad - Rexroad and Nicoll, Pl. 1, figs. 35, 36, 37 (?), 38 (s. f.).

1975 Spathognathodus tauchionensis sp. n. - Саладжюс, р. 221, P1. II, figs. 12 a, b (s. f.).

1976 Spathognathodus polinclinatus Nicoll et Rexroad - Miller, Fig. 8: 25 (s. f.).

1978 Spathognathodus polinclinatus Nicoll et Rexroad - Miller, P1. 2, fig. 23; pl. 4, fig. 25 (s. f.).

1982 Ozarkodina polinclinata (Nicoll et Rexroad) - Aldridge and Mohamed, P1. 2, fig. 35 .

1985 Ozarkodina polinclinata (Nicoll et Rexroad) - Nehring-Lefeld, p. 634, Pl. IV, fig. 8.

Description. The spathognathodiform $(\mathrm{Pa})$ element has an almost straight blade, which on some elements curves slightly inwards at the posterior end. The blade of the large (adult) specimens is laterally thickened below the denticle row. The sharp-pointed laterally compressed denticles are fused nearly to their apices. At the ends of the blade the denticles are inclined accordingly anteriorly and posteriorly; in larger specimens they are higher and larger at the ends of the blade than those in the middle part of it. The small (juvenile) specimens have larger denticles only at the posterior part of the blade, where the posteriorly inclined cusp is situated. In larger specimens the cusp is less prominent.

The shallow basal cavity is situated beneath the posterior part of the blade and is flanked by narrow lips. The cavity narrows towards the ends of the blade. The size and outline of the cavity vary greatly.

The basal margin of the specimens undulates slightly (Plate, figs. 12, $15,17)$.

\section{Explanations to Figs. 3, 4, and 5}

Lithological $\log$ and distribution of the figured specimens of $O$. polinclinata estonica and $O$. polinclinata polinclinata in the Viki (Figs. 3, 4) and Jõhve (Fig. 5) sections. On the left of the logs stratigraphical and zonal divisions are given; on the right are shown the positions of samples.

\section{Legend}

Stratigraphica 1: H'R - Rumba Formation and $H^{\prime} V$ - Velise Formation of the Adavere Regional Stage; $J_{1} M-$ Mustjala Member and $J_{1} N$ - Ninase Member of the Jaani Regional Stage.

Lithological: 1 - coarse-grained skeletal limestone (packstone), 2 - finegrained skeletal limestone (wackestone), 3 - argillaceous limestone, 4 - limestone and dolomite nodules in marlstone, 5 - wave-bedded limestone, 6 - coarse-nodular limestone, 7 - calcareous clay, 8 - argillaceous marlstone, 9 - calcareous marlstone, 10 - dolomitic domerite, 11 - hardground, 12 - metabentonite interbeds.

F a u n a l: 13 - burrows, 14 - solitary corals.

$\mathrm{S}$ a m p le s: 15 - a sample with 0 . polinclinata, 16 - a sample devoid of 0 . polinclinata, 17 - a sample with figured conodont specimens.

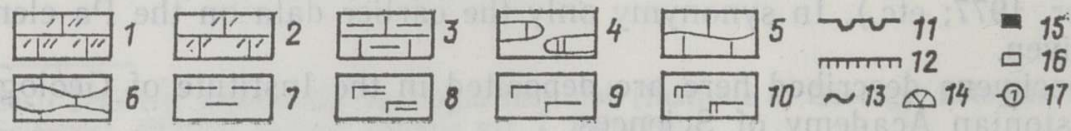


Variation. The variation of the elements seems to be caused mainly by the changes during their growth. The small (juvenile) $\mathrm{Pa}$ elements are short and have relatively high denticles, which are remarkably larger at the posterior end of the blade where the cusp is situated (Plate, figs. 14, 20; Fig. 3, 7; Fig. 5, 19, 23, 24, 25). During the growth the number of the denticles increases and the differences in their sizes decrease.

Remarks. The comparison of $\mathrm{Pa}$ and the notes on the other elements of the apparatus are given under the description of $O$. polinclinata estonica.

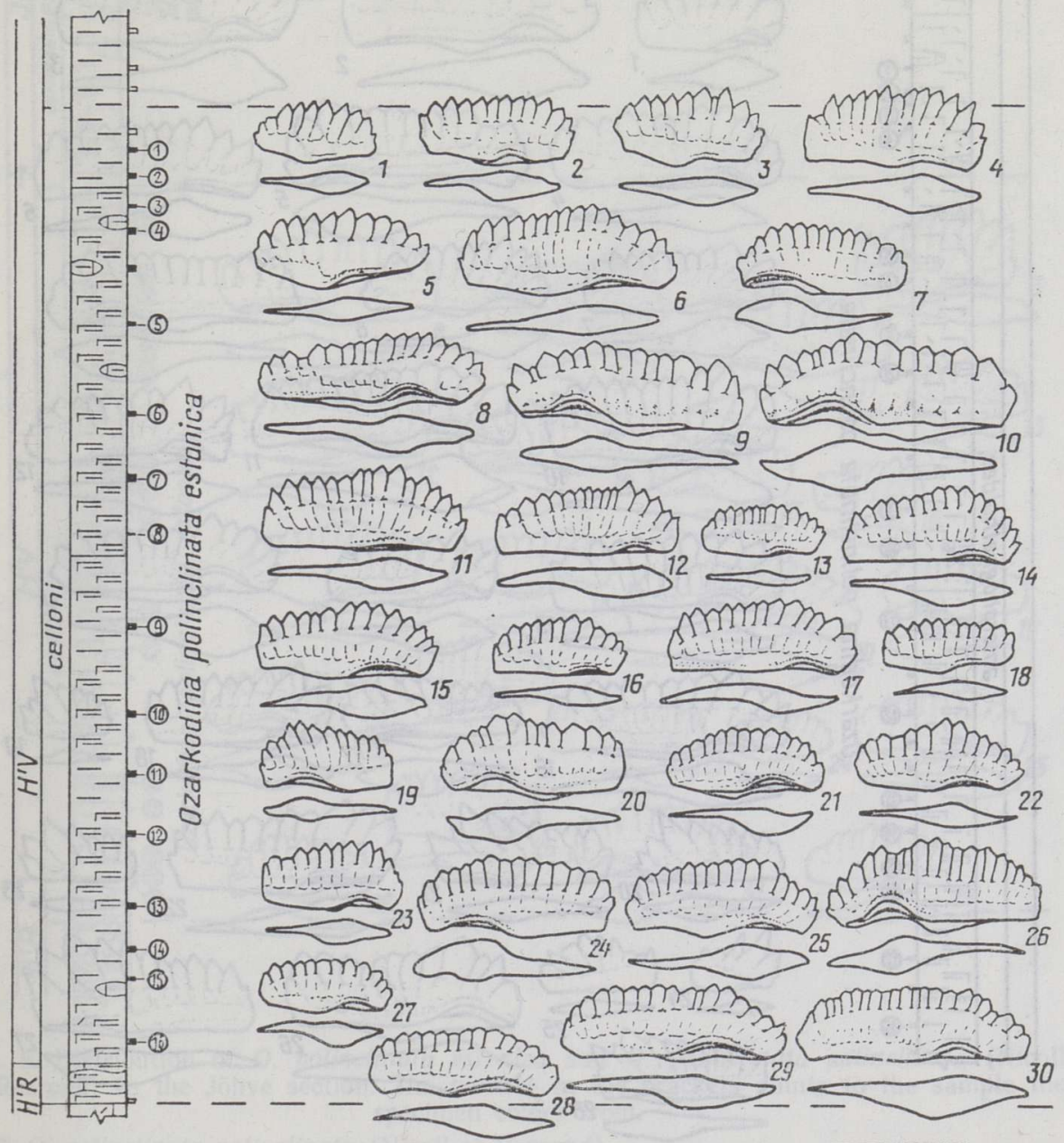

Fig. 3. Distribution of $O$. polinclinata estonica ssp. $\mathrm{n}$. in the lower part of the Viki section. The number in the brackets points to the sample the specimen comes from. 1 - Cn 6404, (1), 152.5-152.7 m; 2-Cn 6396, (2), 153.4-153.5 m; 3- Cn 6390, (3), 154.4-154.5 m; 4-Cn 6391, (3), 154.4-154.5 m; 5 - Cn 6383, (4), 155.2-155.4 m; 6 - Cn 6376, (5), 158.4-158.5 m; 7 - Cn 6374, (5), 158.4-158.5 m; 8 - Cn 6367, (6), 161.5-161.6 m;9-Cn 6355, (7), 163.6-163.8 m; 10-Cn 6356, (7), 163.6-163.8 m; 11 - $\mathrm{Cn} 6344,(8), 165.5-165.6 \mathrm{~m} ; 12-\mathrm{Cn} 6335,(9), 168.6-168.8 \mathrm{~m} ; 13-\mathrm{Cn} 6331$, (9), 168.6-16.8 m; $14-\mathrm{Cn} 6334,(9), 168.6-168.8 \mathrm{~m} ; 15-\mathrm{Cn} 6324,(10), 171.6-$ $171.8 \mathrm{~m} ; 16-\mathrm{Cn} 6323,(10), 171.6-171.8 \mathrm{~m} ; 17-\mathrm{Cn} 6325,(10), 171.6-171.8 \mathrm{~m}$; $18-\mathrm{Cn} 6322,(10), 171.6-171.8 \mathrm{~m} ; 19-\mathrm{Cn} 6316,(11), 173.6-173.8 \mathrm{~m} ; 20-\mathrm{Cn} 6308$, (12), 175.6-175.8 m; $21-\mathrm{Cn} 6300,(13), 178.1-178.2 \mathrm{~m} ; 22-\mathrm{Cn} 6301,(13), 178.1-$ $178.2 \mathrm{~m} ; 23-\mathrm{Cn} 6296,(14), 179.6-179.8 \mathrm{~m} ; 24-\mathrm{Cn} 6287,(15), 180.6-180.7 \mathrm{~m}$; 25 - Cn 6288, (15), 180.6-180.7 m; 26 - Cn 6289, (15), 180.6-180.7 m; 27 - Cn 6276, (16), 182.7-182.9 m; 28-Cn 6277, (16), 182.7-182.9 m; 29-Cn 6278, (16), 182.7$182.9 \mathrm{~m} ; 30-\operatorname{Cn} 6279$, (16), $182.7-182.9 \mathrm{~m}$. 
Occurrence. Upper Llandovery (the uppermost Velise Formation of the Adavere Regional Stage) and the Lower Wenlock (the lowermost Mustjala Beds of the Jaani Regional Stage) in Estonia.

Material. $850 \mathrm{~Pa}, 450 \mathrm{~Pb}, 340 \mathrm{M}, 630 \mathrm{Sc}, 280 \mathrm{Sb}$, and $190 \mathrm{Sa}$ elements.

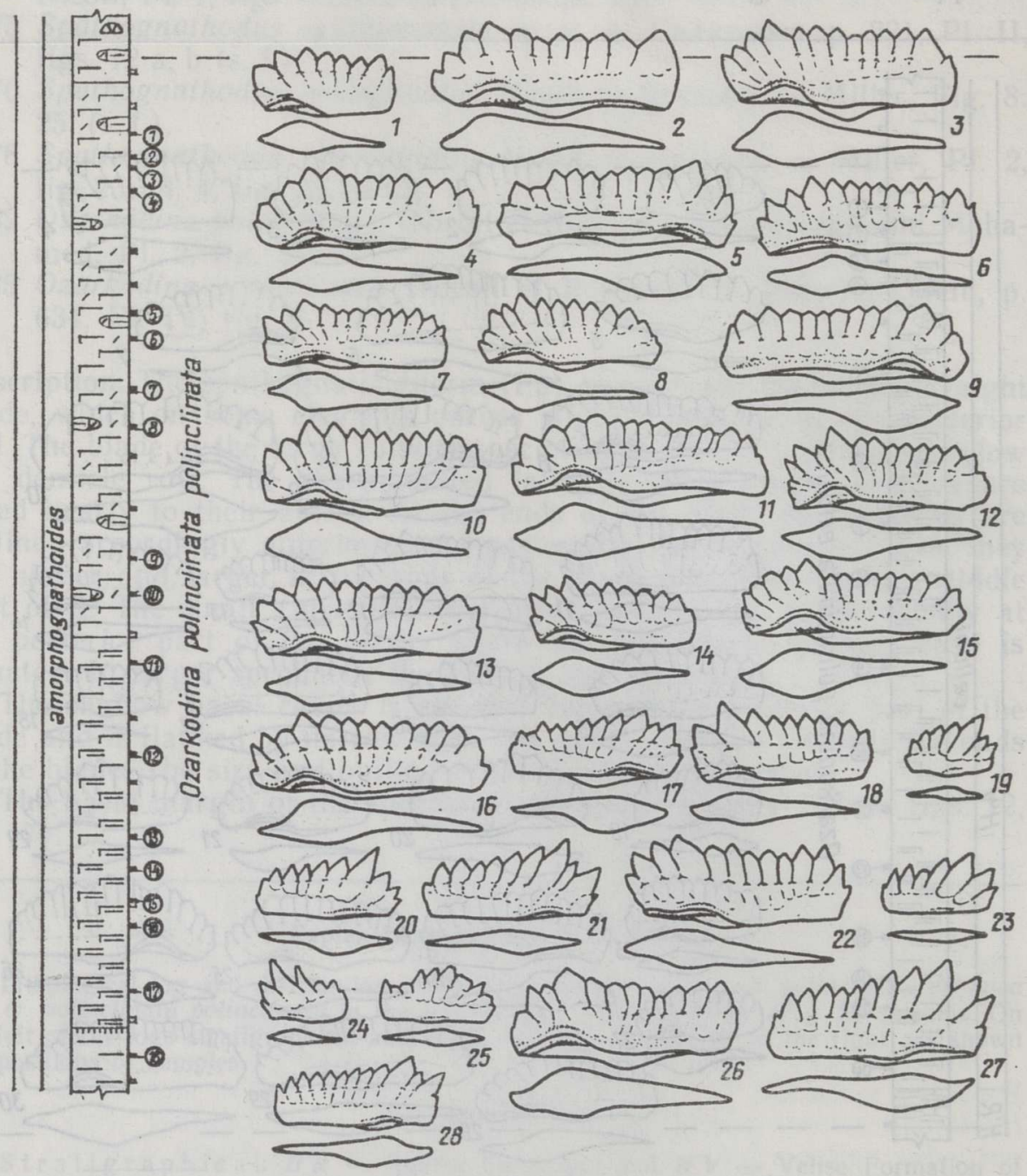

Fig. 4. Distribution of $O$. polinclinata polinclinata (Nicoll et Rexroad) in the upper part of the Viki section. The number in the brackets points to the sample the specimen comes from.

1 - Cn 6556, (1), 114.3-114.4 m; $2-\operatorname{Cn} 6555$, (1), 114.3-114.4 m; 3- Cn 6557, (1), 114.3-114.4 m; 4-Cn 6547, (2), 115.1-115.3 m; 5 - Cn 6543, (3), 115.5-115.6 m;

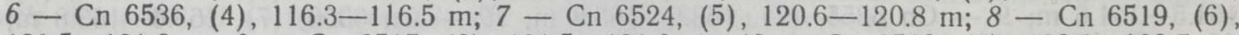
121.5-121.6 m;9- Cn 6517, (6), 121.5-121.6 m; 10- Cn 6513, (7), 123.3-123.5 m; $11-\mathrm{Cn} 6504,(8), 124.6-124.8 \mathrm{~m} ; 12-\mathrm{Cn}_{6505},(8), 124.6-124.8 \mathrm{~m} ; 13-\mathrm{Cn} 6484$, (9), 129.2-129.3 m; $14-\mathrm{Cn} 6471,(10), 130.5-130.6 \mathrm{~m} ; 15-\mathrm{Cn} 6473,(10), 130.5-$ $130.6 \mathrm{~m} ; 16-\mathrm{Cn} 6465,(11), 132.8-132.9 \mathrm{~m} ; 17-\mathrm{Cn} 6445$, (12), $136.1-136.3 \mathrm{~m}$; $18-\mathrm{Cn} 6441,(13), 138.9-139.1 \mathrm{~m} ; 19-\mathrm{Cn} 6435,(14), 140.1-140.3 \mathrm{~m} ; 20-\mathrm{Cn}$ 6433, (15), 141.2-141.3 m; $21-\operatorname{Cn} 6427,(16), 142.1-142.3 \mathrm{~m} ; 22-\mathrm{Cn} 6430$, (16), 142.1-142.3 m; $23-\mathrm{Cn} 6425,(16), 142.1-142.3 \mathrm{~m} ; 24-\mathrm{Cn} 6419,(17), 144.4-$ $144.5 \mathrm{~m} ; 25-\mathrm{Cn} 6420$, (17), 144.4-144.5 m; $26-\mathrm{Cn} \mathrm{6412,} \mathrm{(18),} \mathrm{146.7-146.8} \mathrm{m;}$ 27 - Cn 6411, (18), 146.7-146.8 m; 28 - Cn 6402, (18), 146.7-146.8 m. 


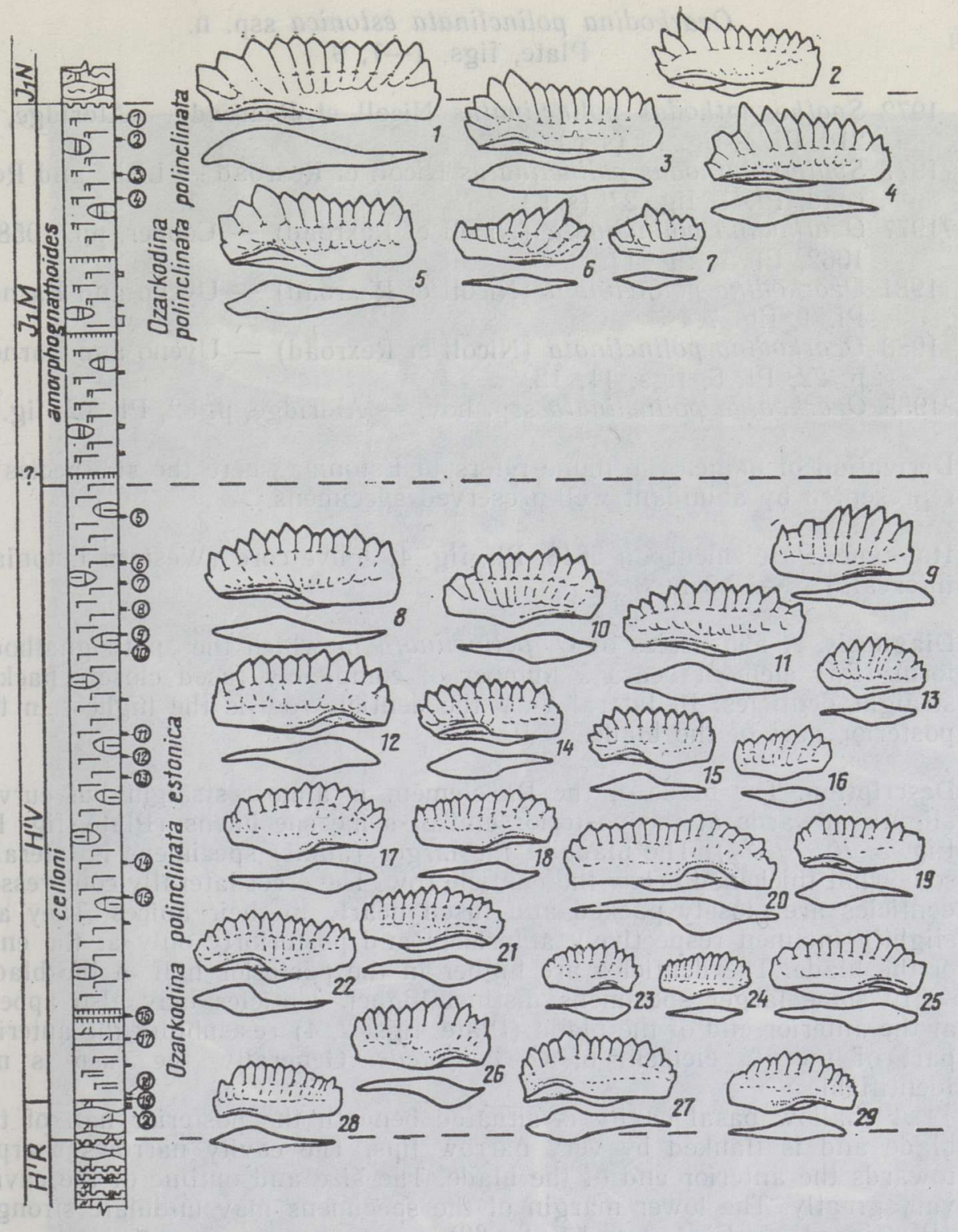

Fig. 5. Distribution of $O$. polinclinata estonica and $O$. polinclinata polinclinata (Nicoll et Rexroad) in the Jõhve section. The number in the brackets points to the sample the specimen comes from.

1-7. O. polinclinata polinclinata (Nicoll et Rexroad).

1 - Cn 6652, (1), 47.1-47.2 m; 2- Cn 6646, (2), 47.9-48.0 m; $3-\mathrm{Cn} \mathrm{6647,} \mathrm{(2),}$ $47.9-48.0 \mathrm{~m} ; 4-\mathrm{Cn} 6645$, (3), 49.3-49.4 m; 5 - $\mathrm{Cn} 6641$, (4), 50.2-50.3 m; 6 Cn 6640, (4), 50.2-50.3 m; 7 - Cn 6639, (4), 50.2-50.3 m.

8-29. O. polinclinata estonica ssp. $\mathrm{n}$.

$8-\mathrm{Cn} 6637$, (5), 62.3-62.4 m; 9- $\mathrm{Cn} \mathrm{6636,} \mathrm{(5),} \mathrm{62.3-62.4} \mathrm{m;} 10-\mathrm{Cn} \mathrm{6635,} \mathrm{(6),}$ $64.0-64.2 \mathrm{~m} ; 11-\mathrm{Cn} 6629,(7), 64.8-64.9 \mathrm{~m} ; 12-\mathrm{Cn} 6620,(8), 65.8-65.9 \mathrm{~m} ; 13-$ Cn 6619, (8), 65.8-65.9 m; $14-\mathrm{Cn} 6617,(9), 66.8-66.9 \mathrm{~m} ; 15-\mathrm{Cn} 6614,(10)$, 67.5-67.6 m; 16 - Cn 6613, (10), 67.5-67.6 m; 17- Cn 6611, (11), 70.6-70.7 m; 18 - Cn 6609, (12), 71.4-71.5 m; 19 - Cn 6604, (13), 72.2-72.3 m; $20-$ Cn 6598, (14), $75.5-75.6 \mathrm{~m} ; 21-\mathrm{Cn} 6597,(14), 75.5-75.6 \mathrm{~m} ; 22-\mathrm{Cn} 6589$, (15), 76.8$76.9 \mathrm{~m} ; 23-\mathrm{Cn} 6574,(16), 81.3-81.5 \mathrm{~m} ; 24-\mathrm{Cn} 6568,(17), 82.2-82.3 \mathrm{~m} ; 25-$ Cn 6570, (17), 82.2-82.3 m; $26-$ Cn 6569, (17), 82.2-82.3 m; $27-$ Cn 6566, (18), 84.3-84.4 m; $28-\mathrm{Cn} 6564,(19), 84.5-84.6 \mathrm{~m} ; 29-\mathrm{Cn} 6559,(20), 84.7-85.0 \mathrm{~m}$. 
1972 Spathognathodus polinclinatus Nicoll et Rexroad - Aldridge, p. 214, Pl. 4, fig. 13 (s. f.).

?1977 Spathognathodus polinclinatus Nicoll et Rexroad - Liebe and Rexroad, Pl. 1, fig. 27 (s. f.).

?1977 Ozarkodina polinclinata (Nicoll et Rexroad) - Cooper, pp. 10581062, P1. 1, fig. 17.

1981 Ozarkodina polinclinata (Nicoll et Rexroad) - Uyeno and Barnes, P1. 1 , fig. 7 .

1983 Ozarkodina polinclinata (Nicoll et Rexroad) - Uyeno and Barnes, p. 22, Pl. 5, figs. 11,12 .

?1985 Ozarkodina polinclinata ssp. nov. - Aldridge, p. 82, Pl. 3.2, fig. 5.

Derivation of name. The name refers to Estonia, where the subspecies is represented by abundant well-preserved specimens.

Holotype. Pa element Cn 5613, Pl., fig. 4; Jõhve core (Western Estonia), interval $79.8-79.9 \mathrm{~m}$.

Diagnosis. A subspecies of $O$. polinclinata in which the spathognathodiform $(\mathrm{Pa})$ element bears a number of completely fused closely packed straight denticles. In lateral view the denticle row is the highest in the posterior part of the blade.

Description. The blade of the $\mathrm{Pa}$ element is almost straight but curves slightly inwards at the posterior end of some specimens (Plate, fig. 1b; Fig. $3,10,20,24$ ). The blade of the larger (adult) specimens is laterally somewhat thickened below the denticle row. The erect laterally compressed denticles are closely packed and fused nearly to their apices. They are slightly inclined respectively anteriorly and posteriorly only at the ends of the blade. The denticles are higher in the posterior half of the blade.

In some larger specimens distinct higher denticles may also appear at the anterior end of the blade (Plate, figs. 2,4) resembling the anterior part of the $\mathrm{Pa}$ element of $O$. confluens. Generally, the cusp is not identifiable.

A shallow basal cavity is situated beneath the posterior half of the blade and is flanked by very narrow lips. The cavity narrows sharply towards the anterior end of the blade. The size and outline of the cavity vary greatly. The lower margin of the specimens may undulate strongly (Pl., figs. $1-3$; Figs. 3 and 5, 8-29).

Figs. 1-7, 9: Ozarkodina polinclinata estonica ssp. n. 1,2, 4- $\mathrm{Pa}$ elements $\mathrm{Cn} 7623$, $\times 100 ; \mathrm{Cn} 7622, \times 100 ; \mathrm{Cn} 5613, \times 50(1 b, 2 b-$ aboral views of 1 and 2$) .3-$ Sa element Cn 6295, $\times 100.5-$ Sc element Cn 5621, $\times 50.6-M$ element Cn $6291, \times 100$. $7-\mathrm{Pb}$ element $\mathrm{Cn} 5616, \times 50.9-\mathrm{Sb}$ element $\mathrm{Cn} 5623, \times 75$.

Figs. 8, 10-20: Ozarkodina polinclinata polinclinata (Nicoll et Rexroad). 8, 10,11- Pb elements Cn 5618, $\times 50$; Cn 7628, $\times 100$; Cn 5617, $\times 50.12,14,15,17,20-\mathrm{Pa}$ elements Cn 6513, × 100; Cn 5215, ×50; Cn 5615, ×50; Cn 5218, ×50; Cn 5614, ×75 (14b, 15baboral views of 14 and 15$)$. $13-\mathrm{Sc}$ element $\mathrm{Cn} 7632, \times 100.16-$ Sb element Cn 7633 , $\times 100,18-M$ element $\mathrm{Cn} 7630, \times 100.19-$ Sa element $\mathrm{Cn} 7635, \times 100$.

Figs. 1, 2, 4, 5, 7, 9 from Jõhve boring core, $79.8-79.9 \mathrm{~m} ; 3,6$ - Viki core, 180.61180.7 m; 8, 11, 14, 15 - Jaagarahu core, 44.6-44.7 m; 10, 12, 13, 16, 18, 19 - Viki core, $168.6-168.8 \mathrm{~m} ; 17,20$ - Jaagarahu core, $47.3 \mathrm{~m}$. 


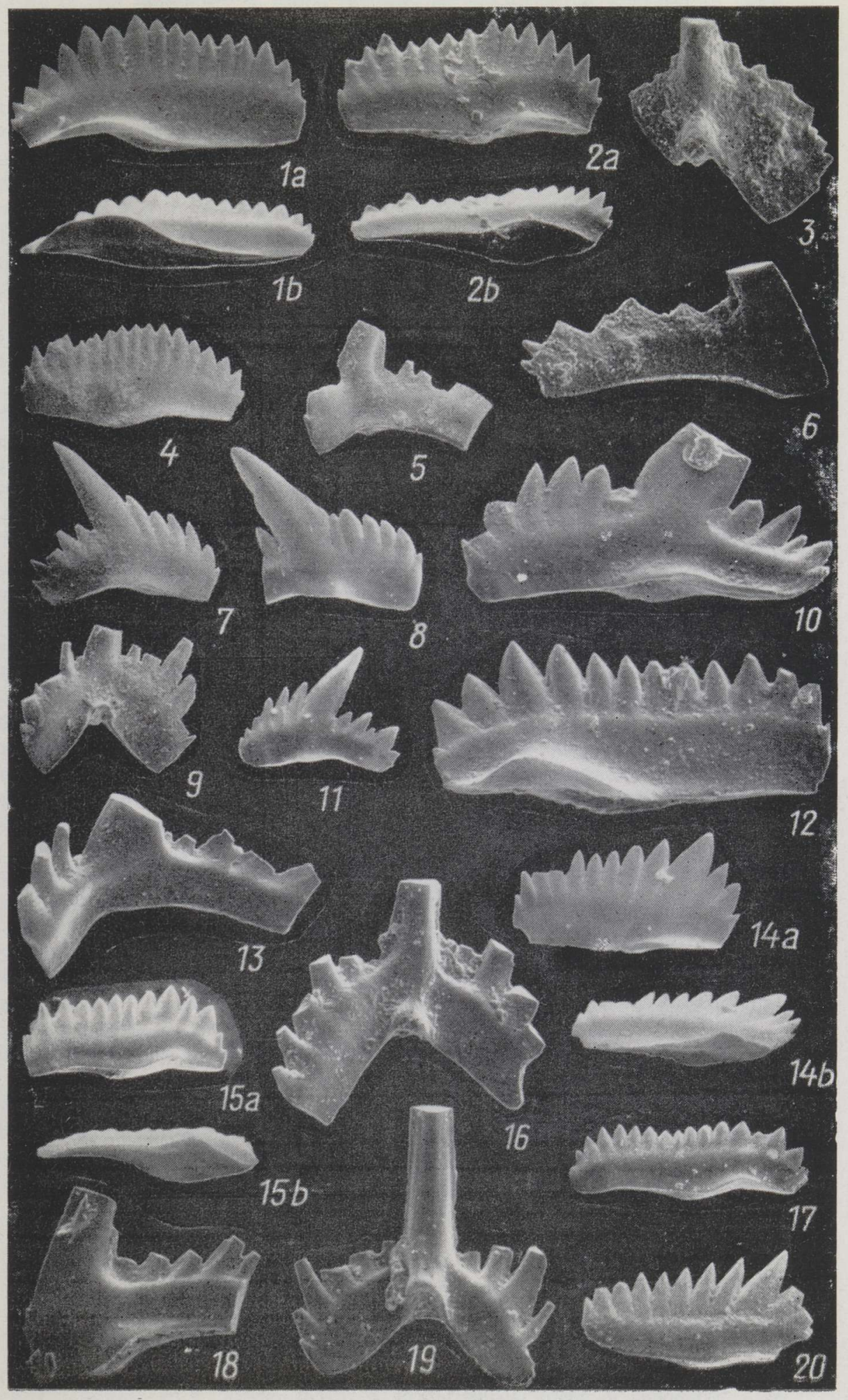



Variation. The new subspecies is remarkably homogeneous. As a rule, the basal margin undulates more notably and the curvature of the arc formed by the tips of the denticles is more regular in the juvenile specimens than in the adult ones (Figs. 3,5). During the growth higher denticles may appear at the anterior end of the blade (Pl., figs. 2, 4).

Comparison. The main difference between the $\mathrm{Pa}$ elements of $O$. polinclinata polinclinata and $O$. polinclinata estonica lies in the character of denticulation of these elements. Denticles of the $\mathrm{Pa}$ elements of $O$. polinclinata estonica are situated more closely and are more completely fused. In most cases the cusp is not identifiable. On the $\mathrm{Pa}$ elements of $\mathrm{O}$. polinclinata polinclinata the denticles are larger (wider) and less fused. Also, their number is smaller than that of $O$. polinclinata estonica and they are more strongly inclined at the ends of the blade.

The most characteristic feature of the $\mathrm{Pa}$ elements of $\mathrm{O}$. polinclinata polinclinata is the posteriorly inclined well-developed cusp in the posterior part of the blade in the majority of the specimens.

Remarks. It is noteworthy that neither of the described apparatuses shows remarkable evolutionary variation.

The absence of transitional forms between $O$. polinclinata estonica and O. polinclinata polinclinata, at least in Estonian sequences, may be caused by a barren interval between their ranges here (Fig. 2).

Although the $\mathrm{Pa}$ elements of $O$. polinclinata polinclinata and $O$. polinclinata estonica differ noticeably, the other elements of these subspecies are similar. They were all fully described in formal taxonomy by Nicoll and Rexroad (1968): Pb as Ozarkodina hanoverensis, Sc - Ligonodina? variabilis, $\mathrm{Sb}-$ Trichonodella asymmetrica, and $\mathrm{Sa}-T$. papilio. The $\mathrm{M}$ element was described by Walliser (1964) as Neoprioniodus planus. The first complete reconstruction of the apparatus $O$. polinclinata was given by Cooper (1977).

The only difference between the $\mathrm{Pb}, \mathrm{M}, \mathrm{Sc}, \mathrm{Sb}$, and $\mathrm{Sa}$ elements of the two described apparatuses is connected with the appearance of more developed lateral thickenings on the blade below the denticle row in O. polinclinata polinclinata (P1.).

In the material from Estonia the elements of both described subspecies are lighter in colour than the elements of the other conodont species, which are amber. It makes them easily recognizable in the faunas.

Occurrence. The upper Llandovery (the uppermost Rumba Formation and the lower part of the Velise Formation of the Adavere Regional Stage) in Estonia.

Material. $650 \mathrm{~Pa}, 290 \mathrm{~Pb}, 230 \mathrm{M}, 340 \mathrm{Sc}, 140 \mathrm{Sb}$, and $70 \mathrm{Sa}$ elements.

Acknowledgements. I am grateful to Drs. V. Viira, H. Nestor, and M. Rubel for their criticism of the text; to Miss U. Moldov and Mr. E. Grünberg for the photos; and to Mrs. K. Ronk for the figures.

REF ERENCES

Aldridge, R. J. 1972. Llandovery conodonts from the Welsh Borderland. - Bull. Brit. Mus. Nat. Hist. (Geol.), 22, 125-231.

Aldridge, R. J. 1985. Conodonts of the Silurian System from the British Isles. - In: A. C. Higgins, R. L. Austin (eds.). A stratigraphical index of conodonts. Ellis Horwood Ltd., 68-92. 
Aldridge, R. J. and Mohamed, I. 1982. Conodont biostratigraphy of the Early Silurian of the Oslo Region. - In: IUGS Subcommission on Silurian Stratigraphy. Field Meeting, Oslo Region 1982. Paleontological Contributions from the University of Oslo, 278, 109-120.

Cooper, B. J. 1977. Toward a familial classification of Silurian conodonts. - J. Paleont., 51, $1057-1071$.

Liebe, R. M. and Rexroad, C. B. 1977. Conodonts from Alexandrian and Early Niagaran rocks in the Joliet, Illinois area. - J. Paleont., 51, 4, 844-857.

Miller, R. 1976. Revision of Upper Ordovician, Silurian, and Lower Devonian stratigraphy, southwestern Great Basin. - Geol. Soc. Am. Bull., 87, 961-968.

Miller, R. 1978. Early Silurian to Early Devonian conodont biostratigraphy and depositional environments of the Hidden Valley dolomite, Southeastern California. J. Paleont., 52, 2, 323-344.

Männik, P. and Aldridge, R. J. 1989. Evolution, taxonomy and relationships of the Silurian conodont Pterospathodus. - Palaeontology, 32, Part 4, 893-906.

Nehring-Lefeld, M. 1985. Konodonty z posiomu amorphognathoides (sylur) wschodniej czesci obnizenia podlaskiego. - Kwartalnik Geologiczny, 29, 3/4, 625-652.

Nicoll, R. S. and Rexroad, C. B. 1968. Stratigraphy and conodont paleontology of the Salamonie Dolomite and Lee Creek Member of the Brassfield Limestone (Silurian) in Southeastern Indiana and adjacent Kentucky. - Department of Natural Resources Geological Survey Bulletin, 40.

Rexroad, C. B. and Nicoll, R. S. 1972. Conodonts from the Estill Shale (Silurian, Kentucky and Ohio) and their bearing of multielement taxonomy. - Geol. et Palaeont., 1, 57-74.

Uyeno, T. T. and Barnes, C. R. 1981. A summary of Lower Silurian conodont biostratigraphy of the Jupiter and Chicotte Formations, Anticosti Island, Quebec. - In: P. J. Lesperance (ed.). Subcommission on Silurian Stratigraphy, OrdovicianSilurian Boundary Working Group. Field Meeting, Anticosti - Gaspe, Quebec 1981, Vol. II: Stratigraphy and Paleontology, 173-184.

Uyeno, T. T. and Barnes, C. R. 1983. Conodonts of the Jupiter and Chicotte Formations (Lower Silurian), Anticosti Island, Quebec. - Geol. Surv. Canada Bull., 355, 49.

Walliser, O. H. 1964. Conodonten des Silurs. - Abhandlungen des Hessischen Landesamtes für Bodenforschung, 41, 106.

Саладжюс В. Ю. 1975. Конодонты лландоверийских (нижнесилурийских) отложений Литвы. - In: Фауна и стратиграфия палеозоя и мезозоя Прибалтики и Белоруссин. Вильнюс, Минтис, 219-226.

Presented by D. Kaljo

Received June 20, 1991

Peep MANNIK

\section{KONODONDILIIGI OZARKODINA POLINCLINATA (NICOLL ET REXROAD) TAKSONOOMIA EESTI ALAMSILURIS}

On kirjeldatud $O$. polinclinata koosseisus kaks alamliiki: $O$. polinclinata polinclinata (Nicoll et Rexroad) ja O. polinclinata estonica ssp. n.

\section{Пээп МЯННИК \\ СОСТАВ КОНОДОНТОВ ВИДА OZARKODINA POLINCLINATA (NICOLL ET REXROAD) В СИЛУPE ЭСТОНИИ}

В составе вида $O$. polinclinata описываются два подвида - 0 . polinclinata polinclinata (Nicoll et Rexroad) и $O$. polinclinata estonica ssp. n. 